\title{
BDNF: A Key Factor with Multipotent Impact on Brain Signaling and Synaptic Plasticity
}

\author{
Przemysław Kowiański $^{1,2}$ (D) Grażyna Lietzau $^{1} \cdot$ Ewelina Czuba $^{1} \cdot$ Monika Waśkow $^{2}$. \\ Aleksandra Steliga ${ }^{2} \cdot$ Janusz Moryś $^{1}$
}

Received: 18 April 2017 / Accepted: 8 June 2017/Published online: 16 June 2017

(c) The Author(s) 2017. This article is an open access publication

\begin{abstract}
Brain-derived neurotrophic factor (BDNF) is one of the most widely distributed and extensively studied neurotrophins in the mammalian brain. Among its prominent functions, one can mention control of neuronal and glial development, neuroprotection, and modulation of both short- and long-lasting synaptic interactions, which are critical for cognition and memory. A wide spectrum of processes are controlled by BDNF, and the sometimes contradictory effects of its action can be explained based on its specific pattern of synthesis, comprising several intermediate biologically active isoforms that bind to different types of receptor, triggering several signaling pathways. The functions of BDNF must be discussed in close relation to the stage of brain development, the different cellular components of nervous tissue, as well as the molecular mechanisms of signal transduction activated under physiological and pathological conditions. In this review, we briefly summarize the current state of knowledge regarding the impact of $\mathrm{BDNF}$ on regulation of neurophysiological processes. The importance of BDNF for future studies aimed at disclosing mechanisms of activation of signaling pathways, neuro- and gliogenesis, as well as synaptic plasticity is highlighted.
\end{abstract}

Przemysław Kowiański

kowiansk@gumed.edu.pl

1 Department of Anatomy and Neurobiology, Medical University of Gdansk, 1 Debinki Street, 80-211 Gdańsk, Poland

2 Department of Health Sciences, Pomeranian University of Slupsk, 64 Bohaterów Westerplatte Str., 76-200 Słupsk, Poland
Keywords BDNF · Cognition · Development · Neurotrophin $\cdot$ Synaptic plasticity

\section{Introduction}

In 1989, Yves-Alain Barde and Hans Thoenen isolated brain-derived neurotrophic factor (BDNF) from pig brain, and shortly afterwards its biochemical structure was revealed (Barde et al. 1982; Leibrock et al. 1989). The human BDNF gene consists of 11 exons, and its different splicing enables formation of transcripts specific to various tissues and responsive to different stimuli (Pruunsild et al. 2007). The conservative structure of BDNF, with 85.9-100\% identity among genes of various vertebrates and humans, determines its physiological function, to a large extent independently of the stage of phylogenetic development (Yeh et al. 2015). BDNF is a member of the neurotrophin family, which also includes nerve growth factor (NGF), neurotrophin 3 (NT3), and neurotrophin 4 (NT4) (Hohn et al. 1990; Ip et al. 1992; Maisonpierre et al. 1990; Rosenthal et al. 1990).

A constantly growing body of evidence indicates involvement of BDNF in a wide range of neurophysiological processes. This can be explained based on its characteristic pattern of synthesis, which involves several biologically active isoforms that interact with different receptors, thereby controlling numerous signaling pathways. BDNF is present in nearly all brain regions (Hofer et al. 1990; Yan et al. 1997). Its function differs depending on both the stage of brain development as well as the neuronal, glial, or vascular constituents of the brain tissue. The most important functions of BDNF include developmental processes, regulation of neuro-, glio-, and synaptogenesis, neuroprotection, and control of short- and long- 
lasting synaptic interactions that influence mechanisms of memory and cognition (for review, see Foltran and Diaz 2016; Gonzalez et al. 2016; Park and Poo 2013; Sasi et al. 2017).

In this review, we present current views on BDNF synthesis and elaborate its active isoforms, their interactions with specific receptors, and hypotheses explaining the role of BDNF in regulation of signaling pathways involved in developmental processes, neuroprotection, and synaptic plasticity.

\section{Functionally Active BDNF Precursor Isoforms are Produced in the Course of Multistage Synthesis}

Synthesis and maturation of BDNF is a multistage process, involving formation of several precursor isoforms. The BDNF protein is synthesized and folded in the endoplasmic reticulum as a precursor form, pre-pro-BDNF (Fig. 1) (Foltran and Diaz 2016; Lu 2003). Upon translocation to the Golgi apparatus, the signal sequence of the pre-region is cleaved, resulting in formation of the precursor proneurotrophin isoform of BDNF (pro-BDNF). This protein consists of 129 amino acids containing an N-terminal pro-domain and 118 amino acids with a C-terminal mature domain (Mowla et al. 2001; Rosenthal et al. 1991). The pro-BDNF is further cleaved to reach the mature isoform (m-BDNF) (Foltran and Diaz 2016; Mizui et al. 2016). Intracellular proteolytic cleavage of pro-BDNF may occur in the trans-Golgi network by constitutively released furin, or in intracellular secretory vesicles by regulated convertases (Lu et al. 2005). Extracellular cleavage of pro-BDNF is dependent on plasmin (Pang et al. 2004) and matrix metalloproteases 2 and 9 (MMP2 and MMP9) (Hwang et al. 2005; Mizoguchi et al. 2011; Vafadari et al. 2016). Secretion of m-BDNF and pro-BDNF into the extracellular space enables their physiological action. The characteristic pattern of neurotrophin synthesis provides, on the one hand, an opportunity to control the enzymatic activity involved in generation of BDNF isoforms, while on the other, it can explain their role in regulation of several physiological processes, frequently having opposite final effects.

Depending on the cell type, BDNF secretion can be constitutive or activity dependent (Mowla et al. 2001). In neuronal cells, both pro-BDNF and m-BDNF are released following cellular membrane depolarization (Conner et al. 1997; Dieni et al. 2012; Yang et al. 2009). The abovementioned mechanisms maintain a dynamic balance between various isoforms of BDNF. The ratio of proBDNF to $\mathrm{m}$-BDNF varies between particular stages of brain development and regions. While in the early postnatal period higher concentration of pro-BDNF is reported,
m-BDNF prevails in adulthood (Yang et al. 2014). Consequently, pro-BDNF may be regarded as an important factor modulating brain function, especially in its development, whereas m-BDNF reveals its significance for processes occurring in adulthood, such as neuroprotection and synaptic plasticity.

Apart from the two above-mentioned isoforms, the functioning of BDNF is significantly affected by the singlenucleotide polymorphism of methionine (Met) to valine (Val) substitution at position 66 within the BDNF gene in the pro-domain encoding region (Egan et al. 2003). According to some recently published data, the Met66 prodomain variant can be regarded as another ligand with independent significance for BDNF communication (for review, see Hempstead 2015).

In conclusion, the multistage pattern of BDNF synthesis and maturation facilitates the contribution of its isoforms to regulation of processes that occur at different stages of brain development, in various cellular populations, as well as in several functional systems.

\section{The BDNF Isoforms Interact with Different Types of Receptors, Triggering a Wide Range of Signaling Cascades}

Pro-BDNF interacts preferentially with the p75 neurotrophin receptor (p75NTR), a member of the tumor necrosis factor (TNF) receptor family, through its mature domain, and with the sortilin receptor or other vacuolar protein sorting 10 protein $(\mathrm{Vps} 10 \mathrm{p})$ of the sorting receptor family, through its pro-domain (Fig. 2) (for review, see Anastasia et al. 2013; Teng et al. 2005). m-BDNF binds the tyrosine kinase $\mathrm{B}$ (TrkB) receptor, belonging to the tropomyosin-related kinase (Trk) family of receptor tyrosine kinases (Chao and Hempstead 1995; Ebendal 1992; Reichardt 2006). In resting form, both types of receptor are located in the membrane of intracellular vesicles. Stimulation with $\mathrm{Ca}^{2+}$, cyclic adenosine monophosphate (cAMP), or electrical impulse initiates their transfer and fusion with the cellular membrane (Du et al. 2000; MeyerFranke et al. 1998).

Activation of p75NTR requires formation of complexes within the cellular membrane which consist of different types of precursor neurotrophins and signaling adaptors. This allows signal transfer and activation of transduction pathways (Chao and Hempstead 1995). The changing composition of such membrane complexes is responsible for the wide spectrum of functions controlled, often with opposing character of final effect, which can vary from supporting neuronal survival to inhibition of growth, or even apoptotic death (Teng et al. 2005). 


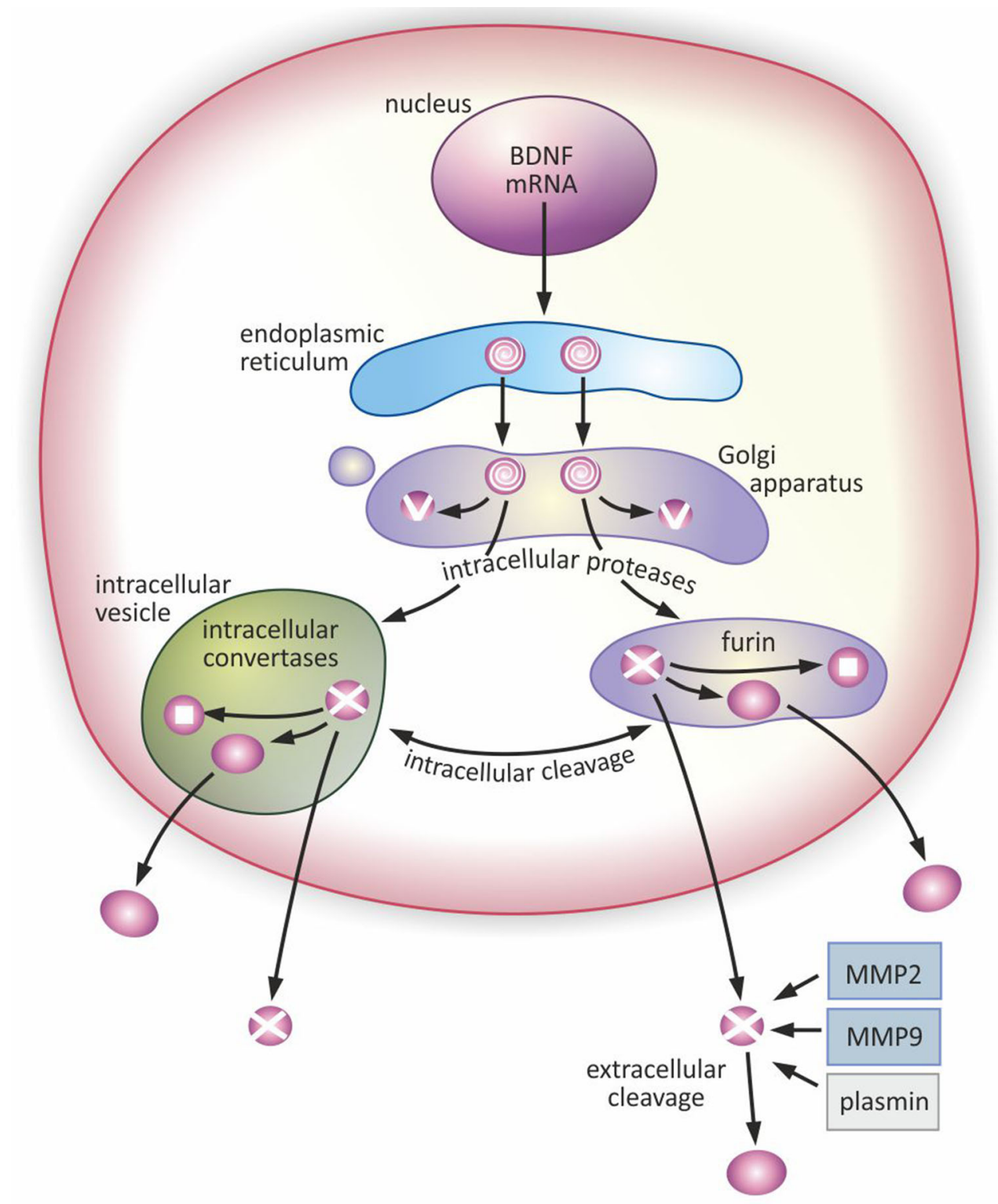

pre- pro-BDNF

\section{5 pro-BDNF}

m-BDNF $\nabla$ pre-region

pro-domain

Fig. 1 Schematic presentation of synthesis and maturation of BDNF. BDNF synthesis and maturation is a multistage sequence of intra- and extracellular processes. In the intracellular pathway, the pre-proBDNF precursor sequence is produced in the endoplasmic reticulum and transported to the Golgi apparatus. In the course of intracellular cleavage, the pre-region sequence is removed, resulting in formation of immature proneurotrophin isoform of BDNF (pro-BDNF). Further, after removal of the pro-domain sequence, the mature isoform of $\mathrm{BDNF}$ ( $\mathrm{m}-\mathrm{BDNF})$ is produced. Intracellular cleavage leading to formation of $\mathrm{m}$-BDNF also occurs in intracellular vesicles, allowing transport of this neurotrophin to axonal terminals and subsequent release into the extracellular space, via presynaptic membrane. Processing of BDNF is accomplished by intracellular proteases, regulated convertases, and furin. As a result, both pro-BDNF and $\mathrm{m}-\mathrm{BDNF}$ isoforms are released into the extracellular space. In the extracellular pathway, pro-BDNF released into the extracellular space is processed by metalloproteinases 2 and 9 (MMP2 and MMP9), plasmin, and extracellular proteases. Consequently, functionally effective isoforms of $\mathrm{m}-\mathrm{BDNF}$ and pro-BDNF can be found in the extracellular space. $B D N F$ brain-derived neurotrophic factor, $m$ $B D N F$ mature isoform of BDNF, $M M P 2$ metalloprotease 2, MMP9 metalloprotease 9, pre-pro- $B D N F$ primary, uncleaved precursor form of $\mathrm{BDNF}$, pre-region region of precursor sequence, pro- $B D N F$ proneurotrophin isoform of BDNF after cleavage of pre-region precursor sequence, pro-domain sequence cleaved from proneurotrophin isoform of BDNF when it becomes mature BDNF 


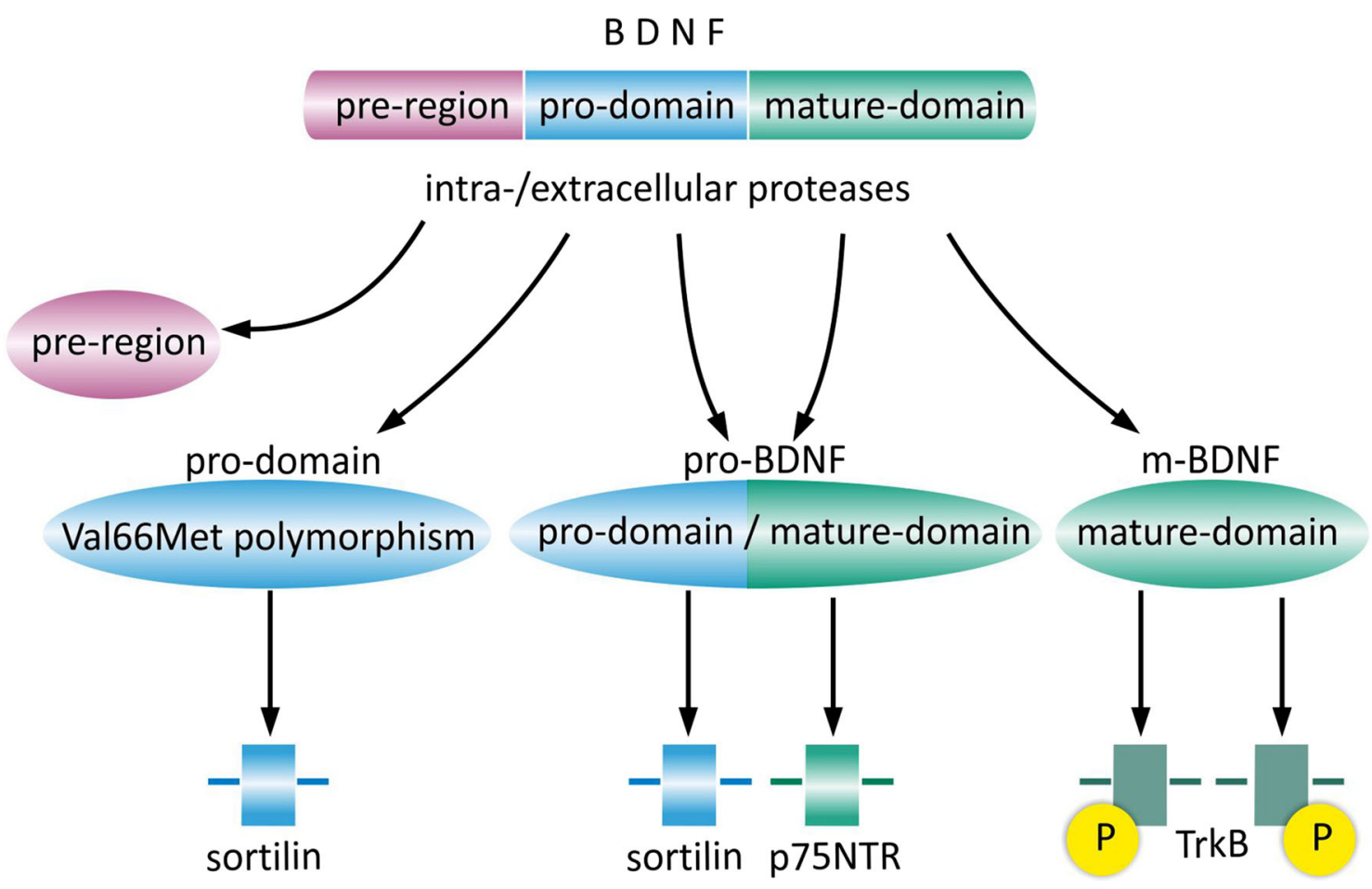

Fig. 2 Interaction of BDNF isoforms with specific receptors. As a consequence of intra- or extracellular cleavage, the primary sequence of pre-pro-BDNF is divided into functionally active isoforms of prodomain, pro-BDNF, and $\mathrm{m}-\mathrm{BDNF}$, each of which exhibits characteristic affinity to a specific type of receptor. The BDNF pro-domain binds preferentially to the sortilin receptor. Although the Val66Met polymorphism of the pro-domain does not exclude its binding with sortilin, the receptor affinity and functional effects resulting from Val66 or Met66 pro-domain binding are characteristic for each of them. The pro-BDNF isoform consisting of two sequences (pro-

Activation of receptors and formation of specific complexes within the cellular membrane triggers several signaling pathways. The pro-BDNF/p75NTR/sortilin binding complex initiates signaling cascades leading to activation of c-Jun amino terminal kinase (JNK), Ras homolog gene family member A (RhoA), and nuclear factor kappa B (NF-KB) (Fig. 3) (Anastasia et al. 2013; Reichardt 2006). The functional implications resulting from activation of the above-mentioned signaling cascades have been systematically studied.

The JNK-related pathway, which is activated by the proBDNF/p75NTR/sortilin complex, triggers neuronal apoptosis (Anastasia et al. 2013; Teng et al. 2005). This mechanism of cell elimination has been confirmed by reports indicating high level of p75NTR expression during brain development and posttraumatic recovery (Barker 1998; Martínez-Murillo et al. 1993; Roux et al. 1999). Activation of the RhoA-dependent signaling pathway is reported to regulate neuronal growth cone development and motility (Reichardt 2006). Finally, p75NTR-dependent activation of NF- $\mathrm{KB}$ supports processes promoting domain and mature domain) interacts with specific receptors (sortilin and p75NTR, respectively). The mature domain of BDNF, being the only constituent of the m-BDNF isoform, exhibits highest affinity for the TrkB receptor, which when stimulated undergoes homodimerization and autophosphorylation. $P$ phosphate group, $p 75 N T R$ p75 neurotrophin receptor, sortilin sortilin-related vacuolar protein sorting 10 protein (Vps10p)-domain sorting receptor 2, TrkB tyrosine kinase B receptor, Val66Met polymorphism polymorphism of BDNF pro-domain resulting from methionine to valine substitution at position 66 within the BDNF gene in the pro-domain encoding region

neuronal survival and maintenance of their adequate number during brain development (Reichardt 2006).

Hence, pro-BDNF binding to specific receptors triggers signaling pathways which can determine neuronal fate via promoting their death or survival. It can also determine the pathway of further development and morphological differentiation. Neurons influenced by high level of proBDNF or remaining under low concentration of m-BDNF prevalently undergo elimination (Bamji et al. 1998). This pattern of pro-BDNF-related regulation can occur during both brain development and postlesion recovery.

The m-BDNF isoform, binding with the high-affinity TrkB receptor, initiates its dimerization and autophosphorylation of intracellular tyrosine residues, which results in formation of phosphorylated-TrkB receptor (Fig. 4) (Kaplan and Miller 2000). An important process determining the stimulatory effect of the m-BDNF/TrkB receptor complex is its translocation toward cellular membrane lipid rafts, i.e., microdomains rich in cholesterol and sphingolipids (Suzuki et al. 2004). PhosphorylatedTrkB activates several enzymes: phosphatidylinositol 
Fig. 3 Intracellular signaling cascades activated by interaction of pro-BDNF isoform with p75NTR and sortilin receptors. The sequences of pro-domain and mature domain (m-BDNF), which form the proneurotrophin isoform (pro-BDNF), reveal preferential affinity for sortilin and p75NTR, respectively. This results in formation of pro$\mathrm{BDNF} / \mathrm{p} 75 \mathrm{NTR} /$ sortilin binding complex and triggering of signaling pathways related with RhoA, NF- $\kappa B$ and JNK, which promotes processes leading to neuronal development and survival, but also to programmed cell death. $J N K$ c-Jun amino terminal kinase, $N F-\kappa B$ nuclear factor kappa B, p75NTR p75 neurotrophin receptor, pro-BDNF proneurotrophin isoform of BDNF, RhoA Ras homolog gene family member A, sortilin sortilin-related Vps10p-domain sorting receptor 2
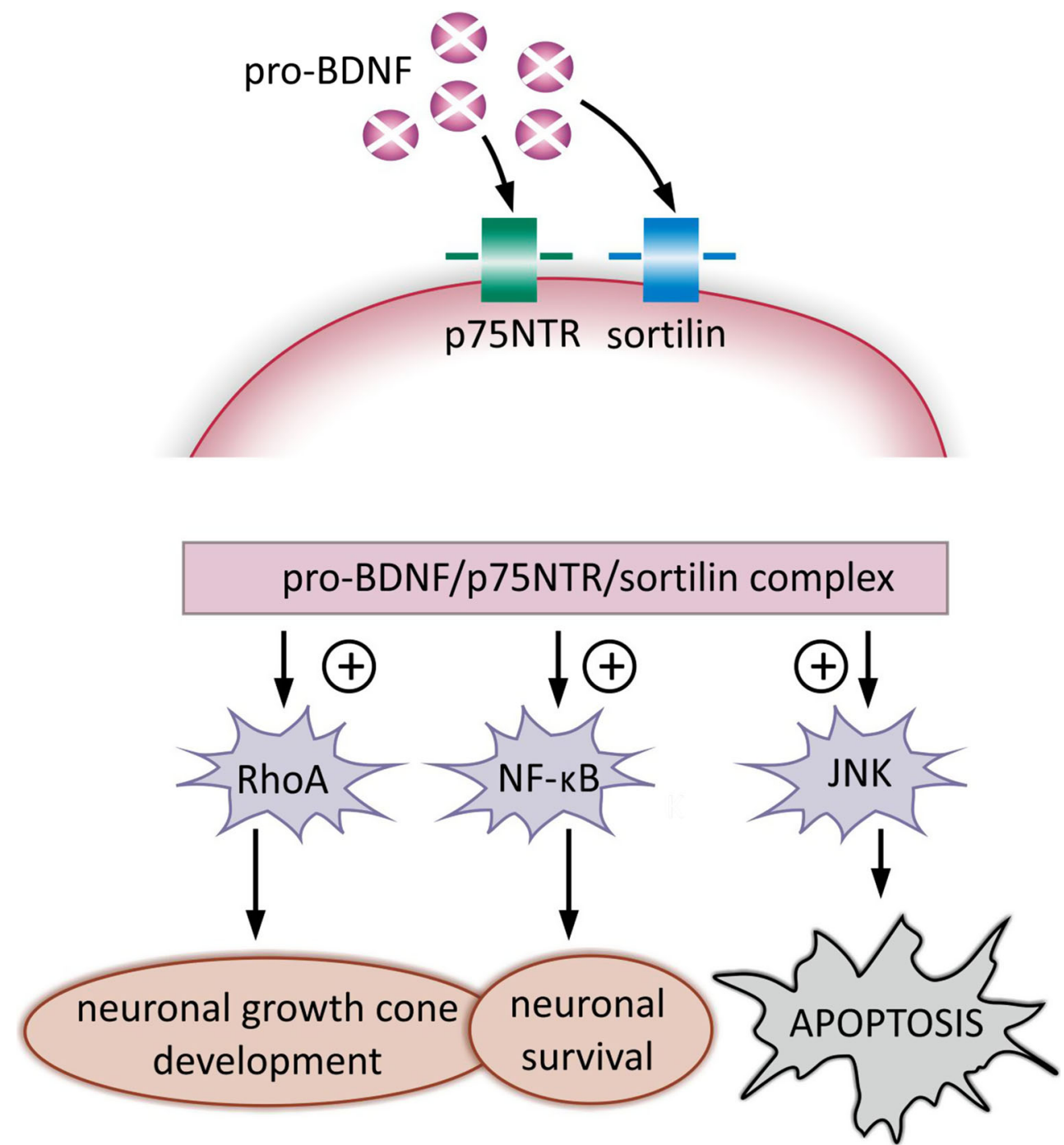

3-kinase (PI3K), mitogen-activated protein kinase (MAPK), phospholipase C- $\gamma$ (PLC- $\gamma$ ), and guanosine triphosphate hydrolases (GTP-ases) of the Ras homolog (Rho) gene family (Gonzalez et al. 2016; Huang and Reichardt 2003; Minichiello 2009). All of these trigger signaling cascades with determined cellular functions.

The PI3K/Akt-related pathway exerts antiapoptotic and prosurvival activity and modulates $N$-methyl-D-aspartate receptor (NMDAR)-dependent synaptic plasticity (Baydyuk and Xu 2014; Gonzalez et al. 2016; Park and Poo 2013). The $\mathrm{PI} 3 \mathrm{~K} / \mathrm{Akt} / \mathrm{mTOR}$ cascade, through regulation of protein synthesis and cytoskeleton development, enhances dendritic growth and branching (Jaworski et al. 2005; Kumar et al. 2005).

The MAPK/Ras signaling cascade regulates protein synthesis during neuronal differentiation (Reichardt 2006). MAPK-related signaling is also required for activation of extracellular-signal-regulated kinase 1/2 (ERK 1/2) and cAMP response element-binding protein (CREB)
(Finkbeiner et al. 1997; Xing et al. 1998). This pathway is critical not only for early response gene expression (e.g., c-Fos and ARC), but also for cytoskeleton protein synthesis (e.g., Arc and cypin) (Gonzalez et al. 2016), as well as dendritic growth and branching in hippocampal neurons (Kwon et al. 2011; Segal 2003).

The PLC- $\gamma$-dependent pathway evokes activation of $\mathrm{Ca}^{2+}$-calmodulin-dependent protein kinase (CAM kinase) and protein kinase $\mathrm{C}$ (PKC), which subsequently increase the 1,2-diacylglycerol (DAG) and $\mathrm{Ca}^{2+}$ ion concentrations (Alcántara et al. 1997; Minichiello 2009). The PKCdependent pathway is reported to enhance synaptic plasticity (Reichardt 2006). BDNF/TrkB complex-initiated activation of GTP-ases, representing the Rho family, stimulates actin and microtubule synthesis, which results in growth of neuronal fibers (Gonzalez et al. 2016).

In summary, the specific role of BDNF in regulation of numerous physiological processes in the brain is a consequence of interaction of its isoforms with different types of 


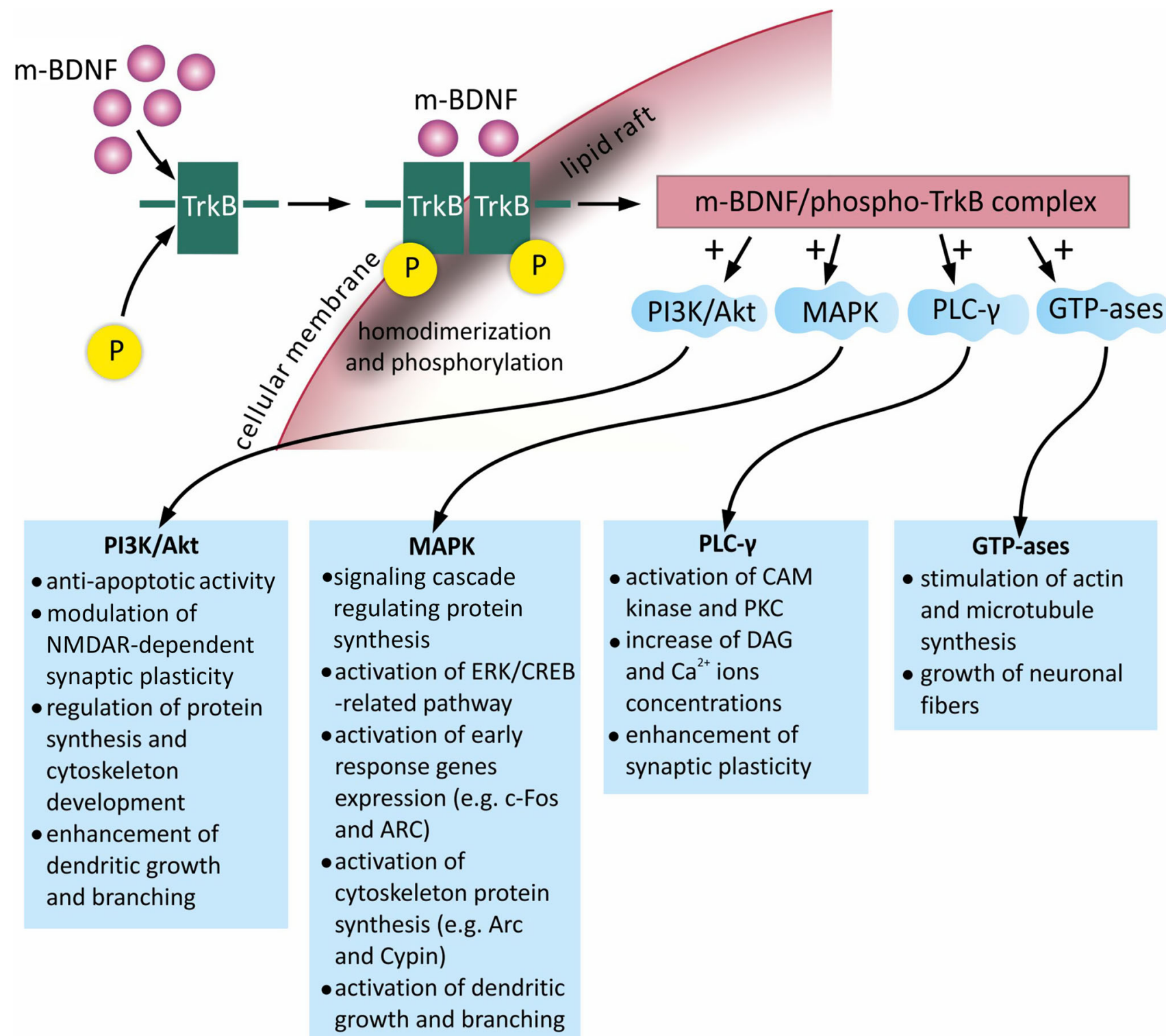

Fig. 4 Intracellular signaling cascades activated by interaction of $\mathrm{m}$-BDNF isoform with TrkB receptor. Binding of the m-BDNF isoform to TrkB receptor triggers its homodimerization and phosphorylation with subsequent translocation to cellular membrane lipid rafts, rich in cholesterol and sphingolipids. The m-BDNF/TrkB receptor complex triggers signaling pathways associated with activation of PI3K, MAPK, PLC- $\gamma$, and GTP-ases of the Rho family. CAM kinase $\mathrm{Ca}^{2+}$-calmodulin-dependent protein kinase, CREB cAMP

response element-binding protein, $D A G$ 1,2-diacylglycerol, $E R K$ extracellular-signal-regulated kinase, GTP-ases guanosine triphosphate hydrolases, $M A P K$ mitogen-activated protein kinase, $m-B D N F$ mature isoform of BDNF, NMDAR $N$-methyl-D-aspartate receptor, $P$ phosphate group, $P I 3 K$ phosphatidylinositol 3-kinase, $P K C$ protein kinase C, $P L C-\gamma$ phospholipase $\mathrm{C}-\gamma$, Rho Ras homolog gene family member, $\operatorname{TrkB}$ tyrosine kinase $\mathrm{B}$ receptor

receptor. This allows triggering of signaling pathways that are critical for maintaining a dynamic balance between stimulating and inhibitory effects exerted upon processes of brain development, synaptic plasticity, and brain regeneration after damage. Understanding the physiological function of BDNF may be critical for further research on regulatory mechanisms of cellular signaling. Disorders of BDNF synthesis, resulting in dysfunction of regulated signaling cascades, may be responsible for triggering several pathological processes.

\section{The BDNF Isoforms Positively and Negatively Contribute to Maintenance of Brain Homeostasis}

One of the most important features of BDNF synthesis is the elaboration of several functionally active isoforms, such as pro-BDNF, m-BDNF, pro-domain sequence, and Val66Met polymorphic pro-domain variant. All of these exert characteristic influences on numerous physiological processes. The positive or negative impact exerted by these 
isoforms enables precise control of the dynamic balance which is essential for maintenance of physiological homeostasis. Additional factors, such as brain developmental stage, brain structure, targeted cellular population, and environmental factors, are also important for this type of regulation.

During brain development, the most important issues related to BDNF isoforms include neuro-, glio-, and synaptogenesis, regulation of cell death, and elimination of improperly formed connections. In adulthood, the prevailing processes enhance the efficiency of stimulus transmission and synaptic plasticity, which support memory and cognition.

The biological function of pro-BDNF has been a subject of discussion for many years (for review, see Gonzalez et al. 2016; Hempstead 2015; Mizui et al. 2016). Initially, it was regarded rather as an inactive protein. However, recently it has been characterized as an independent ligand, demonstrating specific biological activity (Anastasia et al. 2013; Dieni et al. 2012). Among the most important functions of pro-BDNF, one can mention promotion of apoptosis and its negative influence on neuronal remodeling, reflected by growth cone retraction and dendritic spine shrinkage (Gehler et al. 2004; Yamashita et al. 1999). Due to the reduction in the number of neurons and deterioration of synaptic function, these processes contribute to longterm depression (LTD), as revealed in hippocampal neurons (Park and Poo 2013; Woo et al. 2005; Yang et al. 2014). The physiological significance of all these apparently negative processes can be explained by the reduction of an excessive number of maturing neurons, elimination of damaged or malfunctioning cells, as well as elimination of abnormal connections that are ineffective for formation of synaptic plasticity, memory, and cognition.

In contrast to pro-BDNF, m-BDNF supports developmental processes of neuro- and gliogenesis (Gonzalez et al. 2016; Vilar and Mira 2016), neurite outgrowth, dendritic arborization, and dendritic spine formation (Encinas et al. 1999; Yamada et al. 2001). The physiological effect of $\mathrm{m}-\mathrm{BDNF}$ is mainly related to maintenance of synaptic strength and decreased excitability of hippocampal GABAergic interneurons, together enhancing hippocampal longterm potentiation (LTP) (Leal et al. 2015; Park and Poo 2013). Hence, the physiological function of m-BDNF is linked to enhancement of developmental processes, as well as to processes in adulthood that require increased brain activity and support efficient stimulus transmission in the synaptic system, finally resulting in improved memory and cognition.

The results of early studies did not reveal the physiological activity of BDNF pro-domain, but more recent data have shed more light on its potential function (Anastasia et al. 2013). The concentration of BDNF pro-domain rises during adolescence and adulthood, following the increase of m-BDNF, which may provide evidence of its functional significance. It is released from neurons after depolarization, as an activity-dependent ligand with definite physiological properties (Dieni et al. 2012). BDNF pro-domain interacts with the sortilin receptor. However, it reveals different bioactivity depending on the pro-domain variant (Val66 or Met66), most probably due to interaction via different residues. The molecular mechanism of Val66Met polymorphism in BDNF pro-domain relies on its impaired interaction with the sortilin receptor (sortilin-related Vps10p-domain sorting receptor 2) (Chen et al. 2005). This has been postulated to be responsible for altered spatial conformation, changed intracellular sorting and trafficking, as well as impaired release of neurotrophin into the synaptic cleft (Anastasia et al. 2013; Chen et al. 2004, 2005). The consequences of these effects can include changes in neuronal growth cone morphology, or their retraction, as well as impaired synaptic plasticity. There is well-documented evidence indicating that these processes are responsible for initiating characteristic phenotypical manifestations that are critical in the development of several neurodegenerative disorders and processes related to episodic cognition and memory disturbances, increased risk of depression, and anxiety development (Dincheva et al. 2012; Egan et al. 2003; Isackson et al. 1991; Soliman et al. 2010; Verhagen et al. 2010).

\section{The Neuroprotective Effects of BDNF are Related to Modulation of NMDAR/Ca ${ }^{2+}$-Dependent Signaling}

m-BDNF-dependent neuroprotection regulates the dynamic balance between prosurvival NMDAR-dependent synaptic signaling and death-inducing extrasynaptic communication (Lau et al. 2015). The m-BDNF/TrkB receptor complex triggers the synaptic NMDAR/Ca ${ }^{2+}$-driven signaling cascade, leading to increased expression of inhibin $\beta$-A (activin A in homodimer form) (Lau et al. 2015; Zhang et al. 2009). The postulated neuroprotective effect is related to elimination of glutamatergic excitotoxicity, resulting from inhibition of the extrasynaptic NMDAR-mediated $\mathrm{Ca}^{2+}$ influx. This prevents the mitochondrial dysfunction and apoptotic cell death observed in the course of neurodegenerative diseases (Zuccato and Cattaneo 2009).

The neuroprotective effect can also be achieved due to synaptic NMDAR stimulation and subsequent increase of the nuclear $\mathrm{Ca}^{2+}$ influx, which results in activation of CREB and increased expression of genes coding proteins involved in neuroprotection (Bading 2013; Zhao et al. 2017). The above-mentioned mechanisms enable determination of the neuronal fate during brain development and in adulthood. Impairment of these mechanisms has been 
demonstrated in neurodegenerative diseases, such as Huntington's and Alzheimer's (Zuccato and Cattaneo 2009).

\section{BDNF Contributes to Neurogenesis by Modulating Its Advanced Stages}

Among the most important aspects of neurogenesis, one could mention maintenance of an adequate number of proliferating neural progenitors and conditions that enable their further growth and differentiation (Dwyer et al. 2016; Germain et al. 2010). Brain development, on the one hand, relies on coordinated processes of neuro- and gliogenesis, formation of neuronal projections, and synaptogenesis, but on the other hand, is related to programmed cell death and elimination of improperly formed connections, together resulting in the formation of the functionally and morphologically adjusted structure of the adult brain. In spite of intensive studies, the role of BDNF in these processes remains unclear, and available data frequently remain contradictory.

Whereas the prosurvival function of BDNF exerted upon neurons in the developing brain is not evident, it has been reported to enhance survival of neurons in the adult brain after trauma or during neurodegeneration (Ebadi et al. 1997). In vivo studies showed that BDNF is involved in regulation of neurogenesis in the adult hippocampus (Katoh-Semba et al. 2002; Lee et al. 2002; Scharfman et al. 2005). However, some authors question the role of this neurotrophin in survival of new neurons in the adult dentate gyrus (Vilar and Mira 2016).

In the light of current views, based on the results of in vivo studies, the role of BDNF in neurogenesis could be summarized more as a differentiating factor, rather than a survival factor. An accumulating body of evidence indicates action of BDNF during the later stages of neurogenesis (Bergami et al. 2008; Chan et al. 2008; Wang et al. 2015). Binding of BDNF to TrkB receptor stimulates neuronal differentiation and dendritic morphogenesis in the subgranular zone of the hippocampus, confirming its function during advanced stages of neurogenesis. While BDNF deficit does not result in a significant decrease in the number of neurons, it does cause inhibition of dendritic arborization and deteriorated synaptic plasticity (Gao et al. 2009; Rauskolb et al. 2010; Wang et al. 2015). Reduction of BDNF concentration induced in cultured rat hippocampal neurons was related to decreased expression of genes that are functionally related to vesicular trafficking and synaptic communication (Mariga et al. 2015). The pattern of gene expression changes was similar to the profile observed in material coming from patients with Alzheimer's disease and cognitive impairment.
BDNF has been shown to stimulate cellular proliferation in several brain regions. Its overexpression along with p75NTR binding correlated with generation of neuronal precursors in the olfactory bulb (Young et al. 2007; Bath et al. 2008). BDNF is also involved in regulation of migration of neuronal progenitors along the rostral migratory stream and neuronal settlement in the olfactory bulb (Snapyan et al. 2009). Interestingly, BDNF stimulation led to an increase in neuronal number in the olfactory bulb of rat (Benraiss et al. 2001; Henry et al. 2007). However, the same effect was not observed in mouse (Galvao et al. 2008; Reumers et al. 2008), which may be explained by speciesspecific differences in regulatory mechanisms.

An interesting effect revealing the practical significance of BDNF is prosurvival enhancement, exerted upon neurons representing dopaminergic, cholinergic, and serotonergic neurotransmitter systems (Foltran and Diaz 2016). Although an explanation for the role of BDNF in this process requires further study, it indicates an important function of this neurotrophin, potentially related to control of neurotransmitter systems and prevention of development of neurodegenerative or psychiatric disorders.

Apart from the influence of BDNF on development of neuronal subpopulations representing different neurotransmitter systems, results of recent studies have demonstrated a stimulatory effect of the serotoninergic system on BDNF/TrkB receptor complex-initiated neurogenesis (Gould 1999). An increase in neuronal proliferation has been reported after administration of serotonin agonists of several receptors, e.g., 5-HT1A (Banasr et al. 2004; Santarelli et al. 2003), 5-HT2B (Diaz et al. 2012), and 5-HT4 (Mendez-David et al. 2014), which may be related to their binding to the BDNF/TrkB receptor complex. This mechanism could explain the proneurogenic effect of antidepressants from the selective serotonin reuptake inhibitor (SSRI) group. These data may stimulate future studies on the mechanisms of action of SSRIs and extend potential indications in therapy for psychiatric and neurodegenerative disorders.

Sotthibundhu et al. reported a stimulatory effect exerted by amyloid $\beta(\mathrm{A} \beta)$ upon neural progenitor cells in the adult subventricular zone (Sotthibundhu et al. 2009). This effect is mediated by $A \beta$-dependent stimulation of p75NTR, a receptor preferentially binding pro-BDNF, indicating a possible significance of this neurotrophin in neurogenesis. However, this type of $\mathrm{A} \beta$-induced overstimulation of neurogenesis, when occurring in the early stages of development, has been claimed to be responsible for serious disturbances in adult neurogenesis by reducing the number of available neural progenitors.

Another interesting issue that remains to be elucidated is the modulating effect of environmental factors and neuronal activity on the course of BDNF-regulated 
neurogenesis, which has been documented in numerous publications (Berchtold et al. 2005; Cotman et al. 2007; Vaynman and Gomez-Pinilla 2005). Neurogenesis could be induced by environmental enrichment (Kempermann et al. 1997; Rossi et al. 2006), hippocampus-dependent learning (Gould 1999), and physical exercise (Aimone et al. 2014; Vivar et al. 2013). Although the regulatory mechanisms of neurogenesis induced by these factors are complex and only partially disclosed, increased expression of BDNF was found in each case.

Apart from its role in neurogenesis and neuronal differentiation, BDNF has also been reported to stimulate gliogenesis and glial proliferation during brain development and in some pathological processes (Frisen et al. 1993). Results of animal studies have shown increased expression of the truncated TrkB receptor in the region of reactive gliosis after brain injury. Binding of $\mathrm{m}-\mathrm{BDNF}$ to the truncated form of TrkB receptor stimulates gliogenesis and differentiation of neural progenitors into glial lineage (e.g., astrocytes) in conditions of reactive gliosis (Cheng et al. 2007). At the same time, however, it enhances the inhibitory effect upon neurogenesis. This interesting aspect of the function of BDNF, in relationship to the neuroglial reactive response, offers promising opportunities related to modulation of the glial response in the course of various neurodegenerative and neurovascular pathologies. However, this potentially effective strategy, based on BDNF-dependent manipulation of the neuroglial response to pathological stimuli, requires further investigation.

\section{BDNF Modifies Morphological and Functional Aspects of Synaptic Plasticity}

The role of BDNF in regulation of synaptic plasticity and learning mechanisms has been extensively studied both in vivo and in vitro (Messaoudi et al. 2002; Minichiello et al. 1999). BDNF influences both functional and structural aspects of synaptic transmission, enhancing activityinduced changes, which leads to increased efficiency of signal transfer (Lynch 2004). The impact of BDNF can be analyzed along several dimensions, with the final results depending on the level of neuronal activity, the isoform of neurotrophin considered (e.g., pro- or m-BDNF), the time period of the action (short- or long-term effects), its localization (pre- versus postsynaptic effects), and cooperation with neurotransmitters, in particular nitric oxide (NO), glutamate (Glu), and GABA, and their receptors.

Silhol et al. reported that learning increases not only BDNF gene expression but also pro-BDNF and TrkB protein level in hippocampus (Silhol et al. 2007). Moreover, increased level of BDNF in mouse hippocampus evoked by voluntary exercises correlated with improved performance in the Morris water maze test and behavioral tasks related to learning (Vaynman et al. 2004). This is in line with reports showing a correlation between physical activity-evoked BDNF overexpression and augmented excitatory transmission (Canossa et al. 1997; Castren et al. 1993; Patterson et al. 1992; Zafra et al. 1990), as well as enhanced synaptic plasticity in the dentate gyrus (Lynch 2004).

According to an interesting hypothesis, the activitydependent increase of BDNF level is a consequence of stimulation of glutamatergic NMDARs with subsequent $\mathrm{Ca}^{2+}$ intracellular influx. This results in activation of CREB and its binding to BDNF promoter, which leads to initiation of transcription (Ghosh et al. 1994; Tao et al. 1998, 2002; Zafra et al. 1991).

Altogether, BDNF expression depends on various forms of cellular and synaptic activity, initiated by stimuli of different modalities. The relationship between BDNF expression level and stimulus-evoked cellular activity reveals reciprocal character. On the one hand, increased expression of BDNF is the result of stimulation, while on the other hand, higher BDNF content strengthens synaptic potentiation, modulates the axo-dendritic morphology, and positively influences neuronal activity.

Numerous studies have shown that m-BDNF expressed after high-frequency hippocampal stimulation enhanced long-term potentiation (LTP) (Chen et al. 1999; Figurov et al. 1996; Kang et al. 1997; Minichiello et al. 1999). In contrast, pro-BDNF expressed during low-frequency stimulation has been reported to induce LTD (Woo et al. 2005; Yang et al. 2014). These observations confirm a close relationship between the chemical structure of the BDNF isoform and the effects of its action in the context of synaptic plasticity. This can also explain the wide range of BDNF-initiated physiological effects exerted by different stimuli.

Molecular processes responsible for hippocampal synaptic potentiation can be categorized, depending on the time course, into short and long term (Abraham 2003; Kandel 2001; Leal et al. 2015; Sweatt 1999), and BDNF can modify both of them. The short-lasting processes controlled by BDNF are based on regulation of neurotransmitter release, modification of preexisting proteins or synapse structure (Leal et al. 2015). The long-term effects are related to changes in gene expression or protein synthesis (Korte et al. 1998; Park and Poo 2013). The BDNFcontrolled long-lasting effects of LTP and alterations in the synaptic proteome may result from modulation of microRNA (miRNA) expression (Jaitner et al. 2016; Leal et al. 2014; Smalheiser et al. 2010). Another route for synaptic proteome modification, which is dependent on BDNF-related protein degradation, involves calpains and ubiquitin- 
proteasome system activation (Leal et al. 2015; Santos et al. 2015).

Apart from this time-based categorization, the influence of BDNF on synaptic plasticity can also be investigated according to the target of its action, i.e., at pre- or postsynaptic elements. Whereas the former is related to regulation of release of neurotransmitters, the latter is concerned with changes in expression of receptors, their molecular characteristics, as well as regulation of signaling pathways (Edelmann et al. 2014).

The presynaptic effect of BDNF on hippocampal LTP has been reported in Schaffer's collaterals (Zakharenko et al. 2003). This relies on BDNF-induced changes of Glu and GABA release into the synaptic cleft (Figurov et al. 1996). The postsynaptic mechanism of BDNF action has been reported in dentate gyrus (Kovalchuk et al. 2002). In this part of the hippocampus, BDNF modifies the glutamatergic postsynaptic receptors. The m-BDNF/TrkB receptor complex triggers phosphorylation of NR1 and NR2B subunits of NMDA receptor (Caldeira et al. 2007b) and upregulates the GluR1 and GluR2/3 subunits of $\alpha$-amino-3-hydroxy-5methyl-4-isoxazolepropionic acid receptors (AMPARs) (Caldeira et al. 2007a; Fortin et al. 2012). These modifications enhance the synaptic strength and initiate LTP in a $\mathrm{Ca}^{2+}$ ion concentration dependent manner (Kang et al. 1997; Korte et al. 1998; Messaoudi et al. 2002; Minichiello et al. 1999). It has been revealed that the BDNF-dependent increase in the number of AMPARs in the postsynaptic membrane positively enhances LTP, whereas their elimination results in LTD (Derkach et al. 2007; Fortin et al. 2012). Another mechanism of synaptic strength control relies on BDNF-dependent reduction of GABAA receptor expression and decreased inhibitory GABA-ergic neurotransmission in the hippocampus (Jovanovic et al. 2004).

Apart from the above-mentioned molecular mechanisms involving changes in receptor expression, BDNF also induces some structural modifications, enhancing the activity-related efficiency of synaptic transmission. The $\mathrm{BDNF} /$ TrkB receptor signaling cascade triggers processes leading to increase in the number of dendritic spines and increased dendritic arborization, which improves the efficiency of synaptic transmission (Amaral and Pozzo-Miller 2007; Gonzalez et al. 2016; Kumar et al. 2005).

The function of BDNF in modulation of synaptic plasticity is also dependent on its cooperation with neurotransmitters, in particular NO. Although the role of NO in the hippocampal mechanisms of learning and in brain development has been extensively studied, the relationship between NO and neurotrophins involved in these processes remains mostly unknown. Results from recent studies suggest a reciprocal and modulatory relationship between BDNF and NO, which effectively influences synaptic plasticity (Biojone et al. 2015). Binding of BDNF to TrkB receptor upregulates neuronal nitric oxide synthase (nNOS) expression and increases production of NO (Biojone et al. 2015). This effect has been reported in neural progenitors, astrocytes, as well as neocortical and hippocampal neurons (Cheng et al. 2003; Colombo et al. 2012; Kolarow et al. 2014; Sandoval et al. 2011; Xiong et al. 1999).

An interesting hypothesis explaining the role of BDNF and NO in strengthening the synaptic system has been proposed. It has been reported that BDNF-induced increase in NO triggers expression of CREB-dependent genes, which finally results in stimulation of dendritic arborization and enhancement of long-lasting effects of synaptic potentiation (Hardingham et al. 2013; Nott et al. 2008; Riccio et al. 2006). Acting presynaptically, NO can modulate release of Glu and GABA (Steinert et al. 2010). On the contrary, postsynaptic action of NO increases the number of AMPARs, which results in LTP (Malinow and Malenka 2002).

NO-dependent posttranslational modifications of BDNF, such as nitration or $S$-nitrosylation of amino acid residues in the BDNF sequence, negatively change its affinity to TrkB receptor and consequently decrease the impact of BDNF on development of neuronal connections, as well as on synaptic strength as evidenced by LTP (Biojone et al. 2015). Hence, through regulation of NO production, it may be possible to control the BDNF-dependent effects on synaptic plasticity. The physiological significance of BDNF-NO interplay can be attributed to regulation of synaptic strength and elimination of improperly shaped neuronal projections, ultimately resulting in an adequate pattern of connections and maintenance of proper brain functions (Ernst et al. 2000). Better understanding of this relationship requires further research aimed at explaining cognitive, developmental or neuropathological aspects of $\mathrm{NO}$ function.

\section{Conclusions}

A large and constantly growing body of evidence indicates involvement of BDNF in numerous neurophysiological processes. In general, the functions of this neurotrophin are related to control of development of neuronal and glial cells, as well as activity-dependent regulation of the synaptic structure and its maintenance, which are critical for memory and cognition. A wide spectrum of processes are controlled by BDNF, exerting sometimes opposite effects in the brain, which can be explained based on the specific pattern of its synthesis, with several biologically active isoforms that interact with different types of receptor, finally initiating a large number of signaling pathways. The physiological role of BDNF, as summarized herein, renders it a potentially valuable tool for many therapeutic strategies. However, clinical applications of this neurotrophin require further intensive study. 
Acknowledgements Technical assistance from Mrs. Sylwia Scisłowska M.A. is greatly appreciated.

Author Contributions P.K. was responsible for the manuscript concept and design, coordinated the editorial plan, and contributed to manuscript writing and final edition. G.L. contributed to the manuscript concept and writing, and took part in manuscript final edition. E.C. contributed to the manuscript writing and edition. M.W. contributed to the manuscript writing and literature search and selection. A.S. contributed to the manuscript writing and literature search and selection. J.M. provided critical revision of the manuscript final version. All authors critically reviewed content and approved the final version of this publication.

\section{Compliance with Ethical Standards}

Conflict of interest The authors declare that they have no competing interests.

Open Access This article is distributed under the terms of the Creative Commons Attribution 4.0 International License (http://crea tivecommons.org/licenses/by/4.0/), which permits unrestricted use, distribution, and reproduction in any medium, provided you give appropriate credit to the original author(s) and the source, provide a link to the Creative Commons license, and indicate if changes were made.

\section{References}

Abraham WC (2003) How long will long-term potentiation last? Philos Trans R Soc Lond B Biol Sci 358(1432):735-744

Aimone JB, Li Y, Lee SW, Clemenson GD, Deng W, Gage FH (2014) Regulation and function of adult neurogenesis: from genes to cognition. Physiol Rev 94(4):991-1026

Alcántara S, Frisén J, DelRío JA, Soriano E, Barbacid M, SilosSantiago I (1997) TrkB signaling is required for postnatal survival of CNS neurons and protects hippocampal and motor neurons from axotomy-induced cell death. J Neurosci 17(10):3623-3633

Amaral MD, Pozzo-Miller L (2007) TRPC3 channels are necessary for brain derived neurotrophic factor to activate a nonselective cationic current and to induce dendritic spine formation. J Neurosci 27(19):5179-5189

Anastasia A, Deinhardt K, Chao MV, Will NE, Irmady K, Lee FS, Hempstead BL, Bracken C (2013) Val66Met polymorphism of $\mathrm{BDNF}$ alters prodomain structure to induce neuronal growth cone retraction. Nat Commun 4:2490

Bading H (2013) Nuclear calcium signaling in the regulation of brain function. Nat Rev Neurosci 14(9):593-608

Bamji SX, Majdan M, Pozniak CD, Belliveau DJ, Aloyz R, Kohn J, Causing CG, Miller FD (1998) The p75 neurotrophin receptor mediates neuronal apoptosis and is essential for naturally occurring sympathetic neuron death. J Cell Biol 140(4):911-923

Banasr M, Hery M, Printemps R, Daszuta A (2004) Serotonin induced increases in adult cell proliferation and neurogenesis are mediated through different and common 5-HT receptor subtypes in the dentate gyrus and the subventricular zone. Neuropsychopharmacology 29(3):450-460

Barde YA, Edgar D, Thoenen H (1982) Purification of a new neurotrophic factor from mammalian brain. EMBO J 1(5):549-553

Barker PA (1998) p75NTR: a study in contrasts. Cell Death Differ 5(5):346-356

Bath KG, Mandairon N, Jing D, Rajagopal R, Kapoor R, Chen ZY, Khan T, Proenca CC, Kraemer R, Cleland TA, Hempstead BL,
Chao MV, Lee FS (2008) Variant brain-derived neurotrophic factor (Val66Met) alters adult olfactory bulb neurogenesis and spontaneous olfactory discrimination. J Neurosci 28(10): $2383-2393$

Baydyuk M, Xu B (2014) BDNF signaling and survival of striatal neurons. Front Cell Neurosci 8:254

Benraiss A, Chmielnicki E, Lerner K, Roh D, Goldman SA (2001) Adenoviral brain-derived neurotrophic factor induces both neostriatal and olfactory neuronal recruitment from endogenous progenitor cells in the adult forebrain. $\mathrm{J}$ Neurosci 21(17):6718-6731

Berchtold NC, Chinn G, Chou M, Kesslak JP, Cotman CW (2005) Exercise primes a molecular memory for brain-derived neurotrophic factor protein induction in the rat hippocampus. Neuroscience 133(3):853-861

Bergami M, Rimondini R, Santi S, Blum R, Gotz M, Canossa M (2008) Deletion of TrkB in adult progenitors alters newborn neuron integration into hippocampal circuits and increases anxiety-like behavior. Proc Natl Acad Sci USA 105(40):15570-15575

Biojone C, Casarotto PC, Joca SR, Castrén E (2015) Interplay between nitric oxide and brain-derived neurotrophic factor in neuronal plasticity. CNS Neurol Disord 14(8):979-987

Caldeira MV, Melo CV, Pereira DB, Carvalho R, Correia SS, Backos DS, Carvalho AL, Esteban JA, Duarte CB (2007a) Brain-derived neurotrophic factor regulates the expression and synaptic delivery of alpha-amino-3-hydroxy-5-methyl-4-isoxazolepropionic acid receptor subunits in hippocampal neurons. J Biol Chem 282(17):12619-12628

Caldeira MV, Melo CV, Pereira DB, Carvalho RF, Carvalho AL, Duarte CB (2007b) BDNF regulates the expression and traffic of NMDA receptors in cultured hippocampal neurons. Mol Cell Neurosci 35(2):208-219

Canossa M, Griesbeck O, Berninger B, Campana G, Kolbeck R, Thoenen H (1997) Neurotrophin release by neurotrophins: implications for activity-dependent neuronal plasticity. Proc Natl Acad Sci USA 94(24):13279-13286

Castren E, Pitkanen M, Sirvio J, Parsadanian A, Lindholm D, Thoenen H, Riekkinen PJ (1993) The induction of LTP increases BDNF and NGF mRNA but decreases NT-3 mRNA in the dentate gyrus. Neuroreport 4(7):895-898

Chan JP, Cordeira J, Calderon GA, Iyer LK, Rios M (2008) Depletion of central BDNF in mice impedes terminal differentiation of new granule neurons in the adult hippocampus. Mol Cell Neurosci 39(3):372-383

Chao M, Hempstead B (1995) p75 and Trk: a two-receptor system. Trends Neurosci 18(7):321-326

Chen G, Kolbeck R, Barde YA, Bonhoeffer T, Kossel A (1999) Relative contribution of endogenous neurotrophins in hippocampal long-term potentiation. J Neurosci 19(18):7983-7990

Chen ZY, Patel PD, Sant G, Meng CX, Teng KK, Hempstead BL, Lee FS (2004) Variant brain-derived neurotrophic factor (BDNF) (Met66) alters the intracellular trafficking and activity-dependent secretion of wildtype BDNF in neurosecretory cells and cortical neurons. J Neurosci 24(18):4401-4411

Chen ZY, Ieraci A, Teng H, Dall H, Meng CX, Herrera DG, Nykjaer A, Hempstead BL, Lee FS (2005) Sortilin controls the intracellular sorting of brain derived neurotrophic factor to the regulated secretory pathway. J Neurosci 25(26):6156-6166

Cheng A, Wang S, Cai J, Rao MS, Mattson MP (2003) Nitric oxide acts in a positive feedback loop with BDNF to regulate neural progenitor cell proliferation and differentiation in the mammalian brain. Dev Biol 258(2):319-333

Cheng A, Coksaygan T, Tang H, Khatri R, Balice-Gordon RJ, Rao MS, Mattson MP (2007) Truncated tyrosine kinase B brain derived neurotrophic factor receptor directs cortical neural stem 
cells to a glial cell fate by a novel signaling mechanism. J Neurochem 100(6):1515-1530

Colombo E, Cordiglieri C, Melli G, Newcombe J, Krumbholz M, Parada LF, Medico E, Hohlfeld R, Meinl E, Farina C (2012) Stimulation of the neurotrophin receptor TrkB on astrocytes drives nitric oxide production and neurodegeneration. J Exp Med 209(3):521-535

Conner JM, Lauterborn JC, Yan Q, Gall CM, Varon S (1997) Distribution of brain-derived neurotrophic factor (BDNF) protein and mRNA in the normal adult rat CNS: evidence for anterograde axonal transport. J Neurosci 17(7):2295-2313

Cotman CW, Berchtold NC, Christie LA (2007) Exercise builds brain health: key roles of growth factor cascades and inflammation. Trends Neurosci 30(9):464-472

Derkach VA, Oh MC, Guire ES, Soderling TR (2007) Regulatory mechanisms of AMPA receptors in synaptic plasticity. Nat Rev Neurosci 8(2):101-113

Diaz SL, Doly S, Narboux-Nême N, Fernández S, Mazot P, Banas SM, Boutourlinsky $\mathrm{K}$, Moutkine I, Belmer A, Roumier A, Maroteaux L (2012) 5-HT(2B) Receptors are required for serotonin-selective antidepressant actions. Mol Psychiatry 17(2):154-163

Dieni S, Matsumoto T, Dekkers M, Rauskolb S, Ionescu MS, Deogracias R, Gundelfinger ED, Kojima M, Nestel S, Frotscher M, Barde YA (2012) BDNF and its pro-peptide are stored in presynaptic dense core vesicles in brain neurons. J Cell Biol 196(6):775-788

Dincheva I, Glatt CE, Lee FS (2012) Impact of the BDNF Val66Met polymorphism on cognition: implications for behavior genetics. Neuroscientist 18(5):439-451

Du J, Feng LY, Yang F, Lu B (2000) Activity- and Ca(2+)-dependent modulation of surface expression of brain-derived neurotrophic factor receptors in hippocampal neurons. J Cell Biol 150(6): 1423-1434

Dwyer ND, Chen B, Chou SJ, Hippenmeyer S, Nguyen L, Ghashghaei HT (2016) Neural stem cells to cerebral cortex: emerging mechanisms regulating progenitor behavior and productivity. J Neurosci 36(45):11394-11401

Ebadi M, Bashir RM, Heidrick ML, Hamada FM, Refaey HE, Hamed A, Helal G, Baxi MD, Cerutis DR, Lassi NK (1997) Neurotrophins and their receptors in nerve injury and repair. Neurochem Int 30(4-5):347-374

Ebendal T (1992) Function and evolution in the NGF family and its receptors. J Neurosci Res 32(4):461-470

Edelmann E, Lessmann V, Brigadski T (2014) Pre- and postsynaptic twists in BDNF secretion and action in synaptic plasticity. Neuropharmacology 76(Pt C):610-627

Egan MF, Kojima M, Callicott JH, Goldberg TE, Kolachana BS, Bertolino A, Zaitsev E, Gold B, Goldman D, Dean M, Lu B, Weinberger DR (2003) The BDNF val66met polymorphism affects activity-dependent secretion of BDNF and human memory and hippocampal function. Cell 112(2):257-269

Encinas M, Iglesias M, Llecha N, Comella JX (1999) Extracellularregulated kinases and phosphatidyl inositol 3-kinase are involved in brain-derived neurotrophic factor-mediated survival and neuritogenesis of the neuroblastoma cell line SH-SY5Y. J Neurochem 73(4):1409-1421

Ernst AF, Gallo G, Letourneau PC, McLoon SC (2000) Stabilization of growing retinal axons by the combined signaling of nitric oxide and brain-derived neurotrophic factor. J Neurosci 20(4):1458-1469

Figurov A, Pozzo-Miller LD, Olafsson P, Wang T, Lu B (1996) Regulation of synaptic responses to high-frequency stimulation and LTP by neurotrophins in the hippocampus. Nature 381(6584):706-709
Finkbeiner S, Tavazoie SF, Maloratsky A, Jacobs KM, Harris KM, Greenberg ME (1997) CREB: a major mediator of neuronal neurotrophin responses. Neuron 19(5):1031-1047

Foltran RB, Diaz SL (2016) BDNF isoforms: a round trip ticket between neurogenesis and serotonin? J Neurochem 138(2):204-221

Fortin DA, Srivastava T, Dwarakanath D, Pierre P, Nygaard S, Derkach VA, Soderling TR (2012) Brain-derived neurotrophic factor activation of CaM-kinase kinase via transient receptor potential canonical channels induces the translation and synaptic incorporation of GluA1-containing calcium-permeable AMPA receptors. J Neurosci 32(24):8127-8137

Frisen J, Verge VM, Fried K, Risling M, Persson H, Trotter J, Hoekfelt T, Lindholm D (1993) Characterization of glial trkB receptors: differential response to injury in the central and peripheral nervous systems. Proc Natl Acad Sci USA 90(11):4971-4975

Galvao RP, Garcia-Verdugo JM, Alvarez-Buylla A (2008) Brainderived neurotrophic factor signaling does not stimulate subventricular zone neurogenesis in adult mice and rats. J Neurosci 28(50):13368-13383

Gao X, Smith GM, Chen J (2009) Impaired dendritic development and synaptic formation of postnatal-born dentate gyrus granular neurons in the absence of brain-derived neurotrophic factor signaling. Exp Neurol 215(1):178-190

Gehler S, Gallo G, Veien E, Letourneau PC (2004) p75 neurotrophin receptor signaling regulates growth cone filopodial dynamics through modulating RhoA activity. J Neurosci 24(18):4363-4372

Germain N, Banda E, Grabel L (2010) Embryonic stem cell neurogenesis and neural specification. $\mathrm{J}$ Cell Biochem 111(3):535-542

Ghosh A, Carnahan J, Greenberg ME (1994) Requirement for BDNF in activity dependent survival of cortical neurons. Science 263(5153):1618-1623

Gonzalez A, Moya-Alvarado G, Gonzalez-Billaut C, Bronfman FC (2016) Cellular and molecular mechanisms regulating neuronal growth by brain-derived neurotrophic factor (BDNF). Cytoskeleton (Hoboken) 73(10):612-628

Gould E (1999) Serotonin and hippocampal neurogenesis. Neuropsychopharmacology 21(2 Suppl):46S-51S

Hardingham N, Dachtler J, Fox K (2013) The role of nitric oxide in presynaptic plasticity and homeostasis. Front Cell Neurosci $7: 190$

Hempstead BL (2015) Brain-derived neurotrophic factor: three ligands, many actions. Trans Am Clin Climatol Assoc 126:9-19

Henry RA, Hughes SM, Connor B (2007) AAV-mediated delivery of BDNF augments neurogenesis in the normal and quinolinic acidlesioned adult rat brain. Eur J Neurosci 25(12):3513-3525

Hofer M, Pagliusi SR, Hohn A, Leibrock J, Barde YA (1990) Regional distribution of brain-derived neurotrophic factor mRNA in the adult mouse brain. EMBO J 9(8):2459-2464

Hohn A, Leibrock J, Bailey K, Barde YA (1990) Identification and characterization of a novel member of the nerve growth factor/brainderived neurotrophic factor family. Nature 344(6264):339-341

Huang EJ, Reichardt LF (2003) Trk receptors: roles in neuronal signal transduction. Annu Rev Biochem 72:609-642

Hwang JJ, Park MH, Choi SY, Koh JY (2005) Activation of the Trk signaling pathway by extracellular zinc. Role of metalloproteinases. J Biol Chem 280(12):11995-12001

Ip NY, Ibáñez CF, Nye SH, McClain J, Jones PF, Gies DR, Belluscio L, Le Beau MM, Espinosa R, Squinto SP, Persson $\mathrm{H}$, Yancopoulos GD (1992) Mammalian neurotrophin-4: structure, chromosomal localization, tissue distribution, and receptor specificity. Proc Natl Acad Sci USA 89(7):3060-3064 
Isackson PJ, Huntsman MM, Murray KD, Gall CM (1991) BDNF mRNA expression is increased in adult rat forebrain after limbic seizures: temporal patterns of induction distinct from NGF. Neuron 6(6):937-948

Jaitner C, Reddy C, Abentung A, Whittle N, Rieder D, Delekate A, Korte M, Jain G, Fischer A, Sananbenesi F, Cera I, Singewald N, Dechant G, Apostolova G (2016) Satb2 determines miRNA expression and long-term memory in the adult central nervous system. Elife. doi:10.7554/eLife.17361

Jaworski J, Spangler S, Seeburg DP, Hoogenraad CC, Sheng M (2005) Control of dendritic arborization by the phosphoinositide$3^{\prime}$-kinase-Akt-mammalian target of rapamycin pathway. J Neurosci 25(49):11300-11312

Jovanovic JN, Thomas P, Kittler JT, Smart TG, Moss SJ (2004) Brain-derived neurotrophic factor modulates fast synaptic inhibition by regulating GABA(A) receptor phosphorylation, activity, and cell-surface stability. J Neurosci 24(2):522-530

Kandel ER (2001) The molecular biology of memory storage: a dialogue between genes and synapses. Science 294(5544):1030-1038

Kang H, Welcher AA, Shelton D, Schuman EM (1997) Neurotrophins and time: different roles for TrkB signaling in hippocampal longterm potentiation. Neuron 19(3):653-664

Kaplan DR, Miller FD (2000) Neurotrophin signal transduction in the nervous system. Curr Opin Neurobiol 10(3):381-391

Katoh-Semba R, Asano T, Ueda H, Morishita R, Takeuchi IK, Inaguma Y, Kato K (2002) Riluzole enhances expression of brain-derived neurotrophic factor with consequent proliferation of granule precursor cells in the rat hippocampus. FASEB J 10:1328-1330

Kempermann G, Kuhn HG, Gage FH (1997) More hippocampal neurons in adult mice living in an enriched environment. Nature 386(6624):493-495

Kolarow R, Kuhlmann CR, Munsch T, Zehendner C, Brigadski T, Luhmann HJ, Lessmann V (2014) BDNF-induced nitric oxide signals in cultured rat hippocampal neurons: time course, mechanism of generation, and effect on neurotrophin secretion. Front Cell Neurosci 8:323

Korte M, Kang H, Bonhoeffer T, Schuman E (1998) A role for BDNF in the late-phase of hippocampal long-term potentiation. Neuropharmacology 37(4-5):553-559

Kovalchuk Y, Hanse E, Kafitz KW, Konnerth A (2002) Postsynaptic induction of BDNF-mediated long-term potentiation. Science 295(5560):1729-1734

Kumar V, Zhang MX, Swank MW, Kunz J, Wu GY (2005) Regulation of dendritic morphogenesis by Ras-PI3K-Akt-mTOR and Ras-MAPK signaling pathways. J Neurosci 25(49):11288-11299

Kwon M, Fernandez JR, Zegarek GF, Lo SB, Firestein BL (2011) BDNF-promoted increases in proximal dendrites occur via CREB dependent transcriptional regulation of cypin. J Neurosci 31(26):9735-9745

Lau D, Bengtson CP, Buchthal B, Bading H (2015) BDNF reduces toxic extrasynaptic NMDA receptor signaling via synaptic NMDA receptors and nuclear-calcium-induced transcription of inhba/activin A. Cell Rep 12(8):1353-1366

Leal G, Comprido D, Duarte CB (2014) BDNF-induced local protein synthesis and synaptic plasticity. Neuropharmacology 76(PtC):639-656

Leal G, Afonso PM, Salazar IL, Duarte CB (2015) Regulation of hippocampal synaptic plasticity by BDNF. Brain Res 1621:82-101

Lee J, Duan W, Mattson MP (2002) Evidence that brain-derived neurotrophic factor is required for basal neurogenesis and mediates, in part, the enhancement of neurogenesis by dietary restriction in the hippocampus of adult mice. J Neurochem 82(6):1367-1375
Leibrock J, Lottspeich F, Hohn A, Hofer M, Hengerer B, Masiakowski P, Thoenen H, Barde YA (1989) Molecular cloning and expression of brain-derived neurotrophic factor. Nature 341(6238):149-152

Lu B (2003) BDNF and activity-dependent synaptic modulation. Learn Mem 10(2):86-98

Lu B, Pang PT, Woo NH (2005) The yin and yang of neurotrophin action. Nat Rev Neurosci 6(8):603-614

Lynch MA (2004) Long-term potentiation and memory. Physiol Rev 84(1):87-136

Maisonpierre PC, Belluscio L, Squinto S, Ip NY, Furth ME, Lindsay RM, Yancopoulos GD (1990) Neurotrophin-3: a neurotrophic factor related to NGF and BDNF. Science 247(4949 Pt 1):1446-1451

Malinow R, Malenka RC (2002) AMPA receptor trafficking and synaptic plasticity. Annu Rev Neurosci 25:103-126

Mariga A, Zavadil J, Ginsberg SD, Chao MV (2015) Withdrawal of BDNF from hippocampal cultures leads to changes in genes involved in synaptic function. Dev Neurobiol 75(2):173-192

Martínez-Murillo R, Caro L, Nieto-Sampedro M (1993) Lesion induced expression of low-affinity nerve growth factor receptor immunoreactive protein in Purkinje cells of the adult rat. Neuroscience 52(3):587-593

Mendez-David I, David DJ, Darcet F, Wu MV, Kerdine-Römer S, Gardier AM, Hen R (2014) Rapid anxiolytic effects of a 5-HT receptor agonist are mediated by a neurogenesis-independent mechanism. Neuropsychopharmacology 39(6):1366-1378

Messaoudi E, Ying SW, Kanhema T, Croll SD, Bramham CR (2002) Brain-derived neurotrophic factor triggers transcription-dependent, late phase long-term potentiation in vivo. J Neurosci 22(17):7453-7461

Meyer-Franke A, Wilkinson GA, Kruttgen A, Hu M, Munro E, Hanson MG Jr, Reichardt LF, Barres BA (1998) Depolarization and cAMP elevation rapidly recruit $\operatorname{Trk} \beta$ to the plasma membrane of CNS neurons. Neuron 21(4):681-693

Minichiello L (2009) TrkB signalling pathways in LTP and learning. Nat Rev Neurosci 10(12):850-860

Minichiello L, Korte M, Wolfer D, Kühn R, Unsicker K, Cestari V, Rossi-Arnaud C, Lipp HP, Bonhoeffer T, Klein R (1999) Essential role for TrkB receptors in hippocampus-mediated learning. Neuron 24(2):401-414

Mizoguchi H, Nakade J, Tachibana M, Ibi D, Someya E, Koike H, Kamei H, Nabeshima T, Itohara S, Takuma K, Sawada M, Sato J, Yamada K (2011) Matrix metalloproteinase-9 contributes to kindled seizure development in pentylenetetrazole-treated mice by converting pro-BDNF to mature BDNF in the hippocampus. J Neurosci 31(36):12963-12971

Mizui T, Ishikawa Y, Kumanogoh H, Kojima M (2016) Neurobiological actions by three distinct subtypes of brain-derived neurotrophic factor: multi-ligand model of growth factor signaling. Pharmacol Res 105:93-98

Mowla SJ, Farhadi HF, Pareek S, Atwal JK, Morris SJ, Seidah NG, Murphy RA (2001) Biosynthesis and post-translational processing of the precursor to brain-derived neurotrophic factor. J Biol Chem 276(16):12660-12666

Nott A, Watson PM, Robinson JD, Crepaldi L, Riccio A (2008) SNitrosylation of histone deacetylase 2 induces chromatin remodeling in neurons. Nature 455(7211):411-415

Pang PT, Teng HK, Zaitsev E, Woo NT, Sakata K, Zhen S, Teng KK, Yung WH, Hempstead BL, Lu B (2004) Cleavage of proBDNF by tPA/plasmin is essential for long-term hippocampal plasticity. Science 306(5695):487-491

Park H, Poo MM (2013) Neurotrophin regulation of neural circuit development and function. Nat Rev Neurosci 14(1):7-23

Patterson SL, Grover LM, Schwartzkroin PA, Bothwell M (1992) Neurotrophin expression in rat hippocampal slices: a stimulus 
paradigm inducing LTP in CA1 evokes increases in BDNF and NT-3 mRNAs. Neuron 9(6):1081-1088

Pruunsild P, Kazantseva A, Aid T, Palm K, Timmusk T (2007) Dissecting the human BDNF locus: bidirectional transcription, complex splicing, and multiple promoters. Genomics 90(3):397-406

Rauskolb S, Zagrebelsky M, Dreznjak A, Deogracias R, Matsumoto T, Wiese S, Erne B, Sendtner M, Schaeren-Wiemers N, Korte M, Barde YA (2010) Global deprivation of brain-derived neurotrophic factor in the CNS reveals an area-specific requirement for dendritic growth. J Neurosci 30(5):1739-1749

Reichardt LF (2006) Neurotrophin-regulated signalling pathways. Philos Trans R Soc Lond B Biol Sci 361(1473):1545-1564

Reumers V, Deroose CM, Krylyshkina O, Nuyts J, Geraerts M, Mortelmans L, Gijsbers R, Van den Haute C, Debyser Z, Baekelandt V (2008) Noninvasive and quantitative monitoring of adult neuronal stem cell migration in mouse brain using bioluminescence imaging. Stem Cells 26(9):2382-2390

Riccio A, Alvania RS, Lonze BE, Ramanan N, Kim T, Huang Y, Dawson TM, Snyder SH, Ginty DD (2006) A nitric oxide signaling pathway controls CREB-mediated gene expression in neurons. Mol Cell 21(2):283-294

Rosenthal A, Goeddel DV, Nguyen T, Lewis M, Shih A, Laramee GR, Nikolics K, Winslow JW (1990) Primary structure and biological activity of a novel human neurotrophic factor. Neuron 4(5):767-773

Rosenthal A, Goeddel DV, Nguyen T, Martin E, Burton LE, Shih A, Laramee GR, Wurm F, Mason A, Nikolics K, Winslow JW (1991) Primary structure and biological activity of human brainderived neurotrophic factor. Endocrinology 129(3):1289-1294

Rossi C, Angelucci A, Costantin L, Braschi C, Mazzantini M, Babbini F, Fabbri ME, Tessarollo L, Maffei L, Berardi N, Caleo M (2006) Brain-derived neurotrophic factor (BDNF) is required for the enhancement of hippocampal neurogenesis following environmental enrichment. Eur J Neurosci 24(7):1850-1856

Roux PP, Colicos MA, Barker PA, Kennedy TE (1999) p75 neurotrophin receptor expression is induced in apoptotic neurons after seizure. J Neurosci 19(16):6887-6896

Sandoval R, González A, Caviedes A, Pancetti F, Smalla KH, Kaehne T, Michea L, Gundelfinger ED, Wyneken U (2011) Homeostatic NMDA receptor down-regulation via brain derived neurotrophic factor and nitric oxide-dependent signaling in cortical but not in hippocampal neurons. J Neurochem 118(5):760-772

Santarelli L, Saxe M, Gross C, Surget A, Battaglia F, Dulawa S, Weisstaub N, Lee J, Duman R, Arancio O, Belzung C, Hen R (2003) Requirement of hippocampal neurogenesis for the behavioral effects of antidepressants. Science 301(5634):805809

Santos AR, Mele M, Vaz SH, Kellermayer B, Grimaldi M, ColinoOliveira M, Rombo DM, Comprido D, Sebastião AM, Duarte CB (2015) Differential role of the proteasome in the early and late phases of BDNF-induced facilitation of LTP. J Neurosci 35(8):3319-3329

Sasi M, Vignoli B, Canossa M, Blum R (2017) Neurobiology of local and intercellular BDNF signaling. Pflugers Arch Eur J Physiol. doi:10.1007/s00424-017-1964-4

Scharfman H, Goodman J, Macleod A, Phani S, Antonelli C, Croll S (2005) Increased neurogenesis and the ectopic granule cells after intrahippocampal BDNF infusion in adult rats. Exp Neurol 192(2):348-356

Segal RA (2003) Selectivity in neurotrophin signaling: theme and variations. Annu Rev Neurosci 26:299-330

Silhol M, Arancibia S, Maurice T, Tapia-Arancibia L (2007) Spatial memory training modifies the expression of brain-derived neurotrophic factor tyrosine kinase receptors in young and aged rats. Neuroscience 146(3):962-973
Smalheiser NR, Lugli G, Lenon AL, Davis JM, Torvik VI, Larson J (2010) Olfactory discrimination training up-regulates and reorganizes expression of microRNAs in adult mouse hippocampus. ASN Neuro 2(1):e00028

Snapyan M, Lemasson M, Brill MS, Blais M, Massouh M, Ninkovic J, Gravel C, Berthod F, Götz M, Barker PA, Parent A, Saghatelyan A (2009) Vasculature guides migrating neuronal precursors in the adult mammalian forebrain via brain-derived neurotrophic factor signaling. J Neurosci 29(13):4172-4188

Soliman F, Glatt CE, Bath KG, Levita L, Jones RM, Pattwell SS, Jing D, Tottenham N, Amso D, Somerville LH, Voss HU, Glover G, Ballon DJ, Liston C, Teslovich T, Van Kempen T, Lee FS, Casey BJ (2010) A genetic variant BDNF polymorphism alters extinction learning in both mouse and human. Science 327(5967):863-866

Sotthibundhu A, Li QX, Thangnipon W, Coulson EJ (2009) A $\beta(1-42)$ stimulates adult SVZ neurogenesis through the p75 neurotrophin receptor. Neurobiol Aging 30(12):1975-1985

Steinert JR, Chernova T, Forsythe ID (2010) Nitric oxide signaling in brain function, dysfunction, and dementia. Neuroscientist 16(4):435-452

Suzuki S, Numakawa T, Shimazu K, Koshimizu H, Hara T, Hatanaka H, Mei L, Lu B, Kojima M (2004) BDNF-induced recruitment of TrkB receptor into neuronal lipid rafts: roles in synaptic modulation. J Cell Biol 167(6):1205-1215

Sweatt JD (1999) Toward a molecular explanation for long-term potentiation. Learn Mem 6(5):399-416

Tao X, Finkbeiner S, Arnold DB, Shaywitz AJ, Greenberg ME (1998) $\mathrm{Ca}^{2+}$ influx regulates BDNF transcription by a CREB family transcription factor-dependent mechanism. Neuron 20(4):709-726

Tao X, West AE, Chen WG, Corfas G, Greenberg ME (2002) A calcium responsive transcription factor, $\mathrm{CaRF}$, that regulates neuronal activity dependent expression of BDNF. Neuron 33(3):383-395

Teng HK, Teng KK, Lee R, Wright S, Tevar S, Almeida RD, Kermani P, Torkin R, Chen ZY, Lee FS, Kraemer RT, Nykjaer A, Hempstead BL (2005) ProBDNF induces neuronal apoptosis via activation of a receptor complex of p75NTR and sortilin. J Neurosci 25(22):5455-5463

Vafadari B, Salamian A, Kaczmarek L (2016) MMP-9 in translation: from molecule to brain physiology, pathology and therapy. J Neurochem 139(Suppl 2):91-114

Vaynman S, Gomez-Pinilla F (2005) License to run: exercise impacts functional plasticity in the intact and injured central nervous system by using neurotrophins. Neurorehabil Neural Repair 19(4):283-295

Vaynman S, Ying Z, Gomez-Pinilla F (2004) Hippocampal BDNF mediates the efficacy of exercise on synaptic plasticity and cognition. Eur J Neurosci 20(10):2580-2590

Verhagen M, van der Meij A, van Deurzen PA, Janzing JG, AriasVásquez A, Buitelaar JK, Franke B (2010) Meta-analysis of the BDNF Val66Met polymorphism in major depressive disorder: effects of gender and ethnicity. Mol Psychiatry 3:260-271

Vilar M, Mira H (2016) Regulation of neurogenesis by neurotrophins during adulthood: expected and unexpected roles. Front Neurosci 10:26

Vivar C, Potter MC, van Praag H (2013) All about running: synaptic plasticity, growth factors and adult hippocampal neurogenesis. Curr Top Behav Neurosci 15:189-210

Wang L, Chang X, She L, Xu D, Huang W, Poo MM (2015) Autocrine action of BDNF on dendrite development of adultborn hippocampal neurons. J Neurosci 35(22):8384-8393

Woo NH, Teng HK, Siao CJ, Chiaruttini C, Pang PT, Milner TA, Hempstead BL, Lu B (2005) Activation of p75NTR by proBDNF facilitates hippocampal long-term depression. Nat Neurosci 8(8):1069-1077 
Xing J, Kornhauser JM, Xia Z, Thiele EA, Greenberg ME (1998) Nerve growth factor activates extracellular signal-regulated kinase and p38 mitogen-activated protein kinase pathways to stimulate CREB serine 133 phosphorylation. Mol Cell Biol 18(4):1946-1955

Xiong H, Yamada K, Han D, Nabeshima T, Enikolopov G, Carnahan J, Nawa H (1999) Mutual regulation between the intercellular messengers nitric oxide and brain-derived neurotrophic factor in rodent neocortical neurons. Eur J Neurosci 11(5):1567-1576

Yamada M, Suzuki K, Mizutani M, Asada A, Matozaki T, Ikeuchi T, Koizumi S, Hatanaka H (2001) Analysis of tyrosine phosphorylation-dependent protein-protein interactions in TrkB-mediated intracellular signaling using modified yeast two-hybrid system. J Biochem 130(1):157-165

Yamashita T, Tucker KL, Barde YA (1999) Neurotrophin binding to the p75 receptor modulates Rho activity and axonal outgrowth. Neuron 24(3):585-593

Yan Q, Rosenfeld RD, Matheson CR, Hawkins N, Lopez OT, Bennett L, Welcher AA (1997) Expression of brain-derived neurotrophic factor protein in the adult rat central nervous system. Neuroscience 78(2):431-448

Yang J, Siao CJ, Nagappan G, Marinic T, Jing D, McGrath K, Chen ZY, Mark W, Tessarollo L, Lee FS, Lu B, Hempstead BL (2009) Neuronal release of proBDNF. Nat Neurosci 12(2):113-115

Yang J, Harte-Hargrove LC, Siao CJ, Marinic T, Clarke R, Ma Q, Jing D, Lafrancois JJ, Bath KG, Mark W, Ballon D, Lee FS, Scharfman HE, Hempstead BL (2014) proBDNF negatively regulates neuronal remodeling, synaptic transmission, and synaptic plasticity in hippocampus. Cell Rep 7(3):796-806
Yeh FC, Kao CF, Kuo PH (2015) Explore the features of brainderived neurotrophic factor in mood disorders. PLoS ONE 10(6): 0128605

Young KM, Merson TD, Sotthibundhu A, Coulson EJ, Bartlett PF (2007) p75 Neurotrophin receptor expression defines a population of BDNF-responsive neurogenic precursor cells. J Neurosci 27(19):5146-5155

Zafra F, Hengerer B, Leibrock J, Thoenen H, Lindholm D (1990) Activity dependent regulation of BDNF and NGF mRNAs in the rat hippocampus is mediated by non-NMDA glutamate receptors. EMBO J 9(11):3545-3550

Zafra F, Castren E, Thoenen H, Lindholm D (1991) Interplay between glutamate and gamma-aminobutyric acid transmitter systems in the physiological regulation of brain-derived neurotrophic factor and nerve growth factor synthesis in hippocampal neurons. Proc Natl Acad Sci USA 88(22):10037-10041

Zakharenko SS, Patterson SL, Dragatsis I, Zeitlin SO, Siegelbaum SA, Kandel ER, Morozov A (2003) Presynaptic BDNF required for a presynaptic but not postsynaptic component of LTP at hippocampal CA1-CA3 synapses. Neuron 39(6):975-990

Zhang SJ, Zou M, Lu L, Lau D, Ditzel DAW, Delucinge-Vivier C, Aso Y, Descombes P, Bading H (2009) Nuclear calcium signaling controls expression of a large gene pool: identification of a gene program for acquired neuroprotection induced by synaptic activity. PLoS Genet 5(8):e1000604

Zhao H, Alam A, San CY, Eguchi S, Chen Q, Lian Q, Ma D (2017) Molecular mechanisms of brain-derived neurotrophic factor in neuro-protection: recent developments. Brain Res 1665:1-21

Zuccato C, Cattaneo E (2009) Brain-derived neurotrophic factor in neurodegenerative diseases. Nat Rev Neurol 5(6):311-322 